\title{
Exploring Derivatives by Means of GeoGebra
}

\author{
Puspita Sari, Aris Hadiyan, Dwi Antari \\ Universitas Negeri Jakarta, Jl. Rawamangun Muka, RT.11/RW.14, Jakarta 13220, Indonesia \\ e-mail: puspitasari@unj.ac.id
}

\begin{abstract}
Abstrak
Tulisan ini bertujuan untuk menjelaskan bagaimana GeoGebra dapat digunakan dalam pembelajaran kalkulus untuk mengeksplorasi konsep derivative dengan menyediakan visualisasi yang dinamis pada konsep tersebut. Penelitian desain digunakan dalam penelitian ini dengan menyusun instruksional desain (hipotesis lintasan belajar) pada tahap pertama dilanjutkan dengan melaksanakan eksperimen mengajar pada tahap kedua. Data yang diperoleh saat eksperimen berlangsung terdiri dari video rekaman, hasil observasi, interview dan hasil tes mahasiswa. Data tersebut dianalisa secara retrospektif dengan membandingkan proses belajar yang terjadi di kelas dan hipotesis lintasan belajar yang telah disusun. Hasil penelitian menunjukkan bahwa sifat GeoGebra yang dinamis memberikan kemungkinan untuk melihat grafik secara lebih dekat saat garis singgung diperoleh dari garis sekan. Hal ini merupakan dasar untuk pemahaman definisi derivative secara intuitive.
\end{abstract}

Kata Kunci: GeoGebra, derivative, kalkulus, penelitian desain

\begin{abstract}
The paper aims to explain how GeoGebra can be used in a differential calculus course to explore the Derivative concepts by providing dynamic-visualizations of the concept. Design research methodology was used in this research by designing an instructional design (hypothetical learning trajectories) in the first phase and conducting the teaching experiment in the second phase. The data collected during the experiment consist of video recordings of the classroom activities, observations, interviews, and students written work. In the third phase of the design research, the data were analyzed retrospectively by comparing the actual learning process and the hypothetical learning trajectory. The results show that the dynamic feature of GeoGebra offers the possibility of zooming in on a graph corresponds to taking infinitesimal when a secant line transforms into a tangent line. This builds a foundation for the understanding of the definition of derivative intuitively.
\end{abstract}

Keywords: GeoGebra, derivatives, calculus, design research

How to Cite: Sari, P., Hadiyan, A., \& Antari, D. (2018). Exploring derivatives by means of GeoGebra. International Journal on Emerging Mathematics Education, 2(1), 65-78. http://dx.doi.org/10.12928/ijeme.v2i1.8670

\section{INTRODUCTION}

Over the last few decades, the use of innovative technology in calculus teaching and learning has been an interest in mathematics education (Gravemeijer \& Doorman, 1999; Hohenwarter et al., 2008; Özmantar et al., 2009; Diković, 2009; Haciomeroglu \& Andreasen, 2013). By means of technology, the teaching and learning of calculus have shifted into more active and dynamic where students can explore various mathematical concepts with multi representations, which is often difficult without using technology. Previous studies (Zimmerman, 1991; Ahuja et al., 1998; Gravemeijer \& Doorman, 1999; Lee, 2006; Weigand, 2014) suggested the importance of multiple representations and connections among them in calculus teaching and learning for a 
more meaningful understanding of the concepts. Having students construct and visualize mathematical objects from a different perspective can help them synthesize analytic and visual thinking, a process that will enhance their conceptual understanding (Haciomeroglu et al., 2009).

In this research, a dynamic mathematics software GeoGebra was used in exploring derivative concepts. GeoGebra is an open-source software for mathematics teaching and learning that offers geometry, algebra and calculus features in a fully connected and easy-to-use software environment. GeoGebra's interface consists of an algebra view and a geometry view or a graphic view (see Figure 1) and it offers the possibility to create mathematical objects dynamically. Mathematical objects can be constructed by entering values into the input bar or using the geometry tools from the toolbar, and their algebraic (or numeric) and graphic representations will be displayed in the algebra and geometry windows respectively. By using GeoGebra, students are able to construct, manipulate, and give arguments about mathematical objects (Hohenwarter et al., 2008).

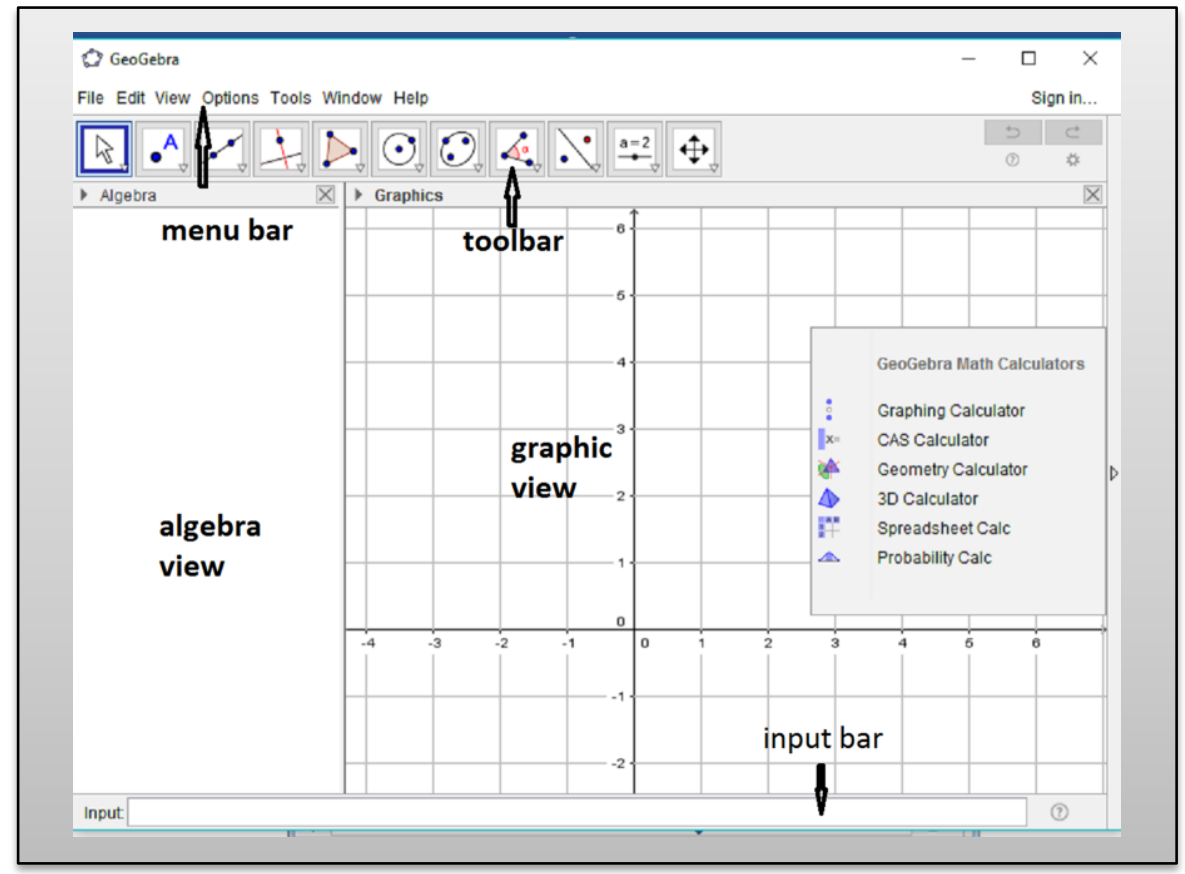

Figure 1. GeoGebra's Interface

GeoGebra provides tools that can be used to develop and explore calculus ideas. Tall (2009) stated that calculus is fundamentally a dynamic conception and the use of technology can help students to build up dynamic embodied concepts in calculus. For example, tracing the changing slope of a curve's tangent gives a physical embodiment of a curve's tangent that can be estimated numerically or investigated symbolically to give a precise description (Tall, 2009). In conjunction with this, Leibniz explained how to find a tangent line (as cited in Kleiner 2001; Struik 1969): to find a tangent means to draw a line that connects two points of the curve at an infinitely small distance, or the continued side of a polygon with an infinite number of angles, which for us takes the place of the curve. This infinitely small distance can always be expressed by a known differential like $d s$ (see Figure 2). 


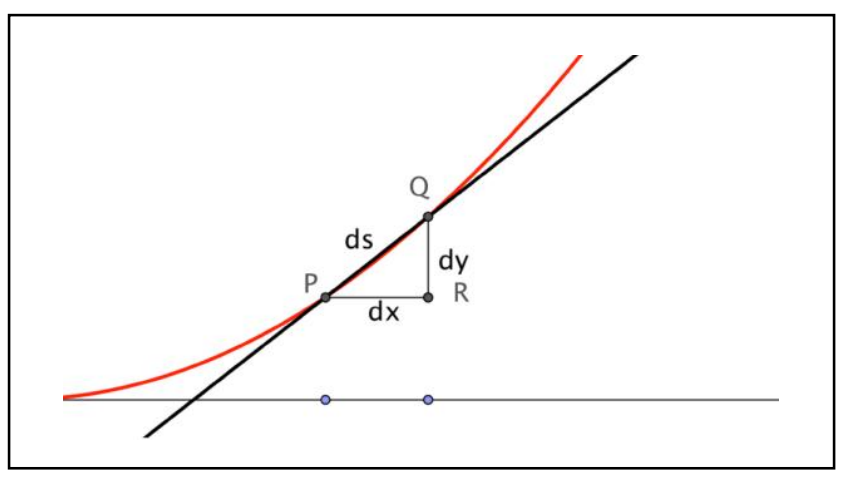

Figure 2. The Leibniz triangle

Students' difficulties in understanding the concept of calculus are the result of a poor understanding of the geometrical and algebraic aspects of the concept (Haciomeroglu et al., 2010; Zimmerman, 1991). By using a dynamic GeoGebra software that brings together algebra and geometry aspects in calculus is believed to develop students' conceptions of the derivative by taking into account the visual thinking to the concept. However, it is argued that although technology plays a role to integrate visualization with numerical and symbolic aspects of calculus, the integration must be built into the structure of the course and into the design of particular topics and problems (Zimmerman, 1991). In conjunction with that, Amiel \& Reeves (2008) suggested that educational technology researchers should be concerned with examining the technological process as it unfolds in schools and universities and its relationship to larger society.

Despite the numerous studies in the teaching-learning of calculus, it is noteworthy that the research in calculus learning and teaching has not capitalized on advances in design research to further link theories of learning with theories of instructional design (Rasmussen et al., 2014). Design-based research provides a cycle that promotes the reflective and long-term foundation upon which such research can be undertaken (Amiel \& Reeves, 2008). Moreover, design research provides a productive perspective for theory development, and results of design research which encompass the design of activities, materials, and systems are the most useful results regarding the improvement of the education system as the ultimate goal of educational research (Edelson, 2002). Therefore, aiming at the development of learning trajectories about students' learning of calculus derivative concept by means of GeoGebra, the present research attempts to answer the question: how GeoGebra can be used in a calculus differential course to explore derivative concepts by providing dynamic-visualizations of the concept?

\section{RESEARCH METHOD}

In order to answer the research question, the design research methodology was used in this research by conducting three phases consisting of the design and preparation phase (thought experiment), the teaching experiment phase (instruction experiment), and the retrospective analysis phase (Gravemeijer \& Cobb, 2006; Cobb et al., 2003). Each of these forms a cyclic process both on its own and in a whole design research. Therefore, the design experiment consists of cyclic processes of thought experiments and instruction experiments (Freudenthal, 1991).

In the first phase of the design research, an instructional design or the hypothetical learning trajectory (HLT) was developed by taking into account the 
literature and the previous studies in the field. The contributions of other lecturers of calculus course were also worth in developing the HLT, including the means designed to ensure the internal validity of this research. The hypothetical learning trajectory (HLT) is made up of three components: the learning goal that defines the direction, the learning activities, and the hypothetical learning process-a prediction of how the students' thinking and understanding will evolve in the context of the learning activities. (Simon, 1995). The HLT not only functions as a guideline for carrying out the teaching experiment and the retrospective analysis, but also provides justifications, hypotheses, and expectations in the choices made. It must be reported in such a manner that it can be retracted, or virtually replicated by other researchers (Gravemeijer \& Cobb, 2006). A criterion for virtual replicability is 'trackability' (Cobb et al., 2001).

The second phase is the teaching experiment which was conducted in the Department of Mathematics, State University of Jakarta (Universitas Negeri Jakarta) during the course Differential Calculus in year 2016/2017 in a class of 44 students enrolled in the course. The experiment consists of two lessons, focusing on developing students understanding of the definition of derivatives and constructing derivative graphs. In the first lesson, the students worked in front of a computer with GeoGebra software installed, although in the second lessons the students only observed how the lecturer demonstrated GeoGebra due to some limitations. The data collected during the teaching experiment was a video recording of the classroom activities, observations, interviews, students' written work, and field notes.

The data were analyzed retrospectively by comparing the actual learning process and the hypothetical learning trajectory. Every meeting was videotaped and some critical moments during the lessons were transcribed or summarized. Observations took place on the classroom level, group level, and individual level, while interviews were made occasionally during the lesson or purposively after the lesson. Students' written work was chosen, examined and analyzed in accordance with other sources of data to improve the triangulation.

\section{RESULTS AND DISCUSSION}

Following are the descriptions of the instructional design or the hypothetical learning trajectory (HLT) along with the results obtained from the teaching experiment. The retrospective analysis is explained sequentially with the result. The analysis focus on how the use of GeoGebra can contribute to the development of students' conception of the derivative.

\section{Approaching Tangent Line from Secant Line}

The objective of this lesson is that students will be able to trace the changing slope of a tangent line to a curve by observing the infinitely small distance between two points intersect the curve. By doing so, students were expected to develop an intuitive understanding about taking the limit process in determining the slope of a curve's tangent. The concept of limit is said to be one of the essential concepts in calculus because it underpins the concepts of derivatives and integrals. It can be seen from the diagram (see Figure 3) that the concepts of the tangent to a curve and rate of change underlie the concept of Limits, where Limit is essential to the development of the concepts of derivatives and integrals in calculus. 


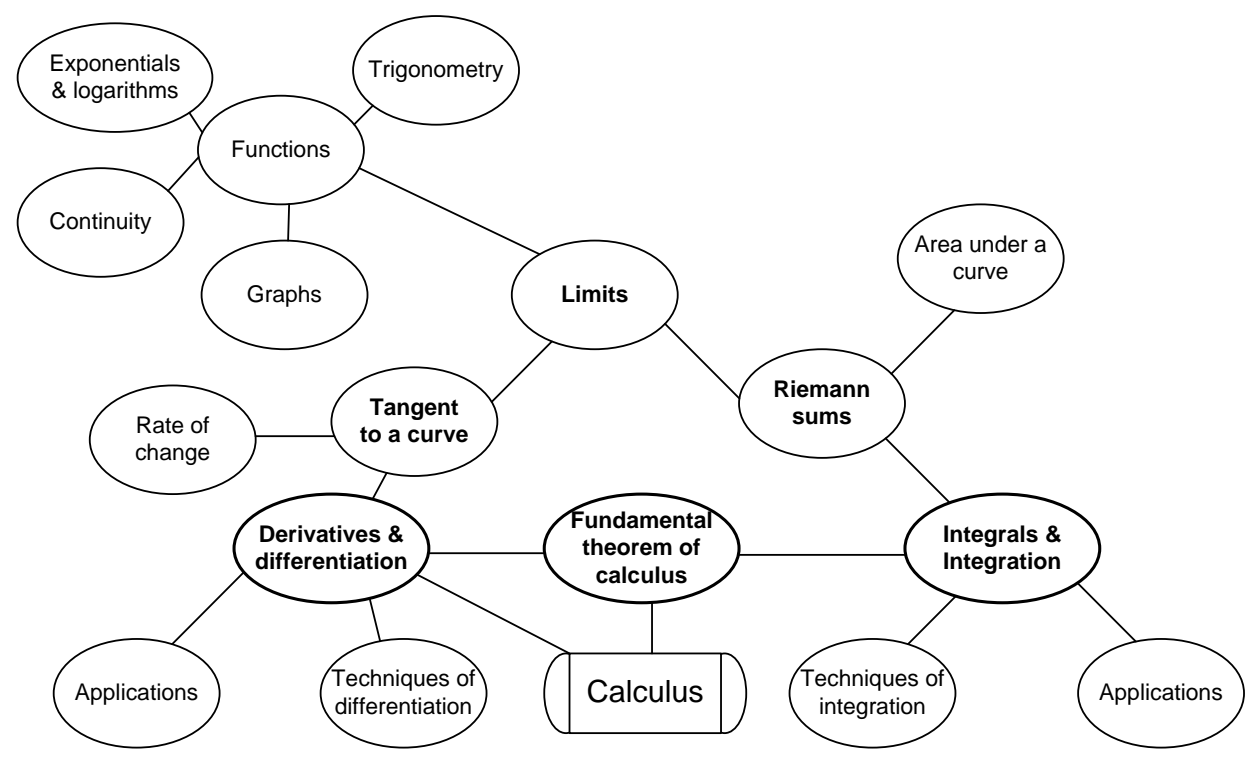

Figure 3. The concepts that underlie calculus concept (source: Lee, 2006.)

However, it seems that students have a distinct understanding of limits and derivatives. Students tend to think derivatives as a procedure to obtain another function in which the degree of the derivative is one less than the degree of the initial function. It can be seen from the transcript (see Figure 4) where the conversation took place at the beginning of the lesson.

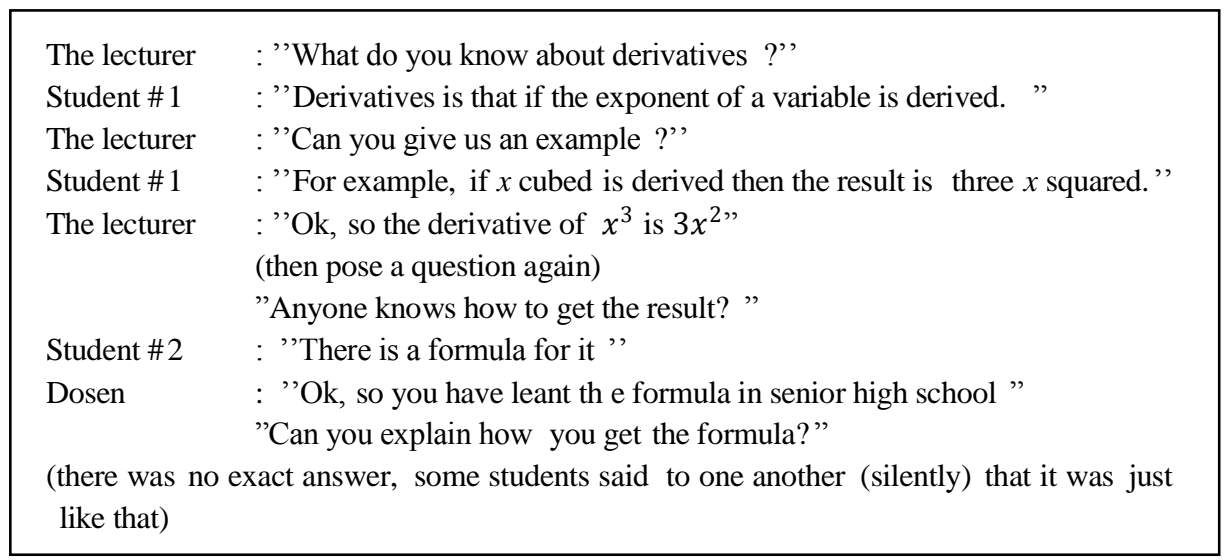

Figure 4. Students' perception of derivative

Therefore, the following activities were chosen in order to develop students' conception about derivatives, not merely its procedural understanding but also conceptual understanding by providing a dynamic visualization of the concept. GeoGebra was chosen as the means because its dynamic feature can demonstrate the infinitesimal elements in geometrical figures when a secant line transforms into a tangent line.

In this activity, the lecturer demonstrated how a tangent line is obtained from a secant line. Figure 5 shows the GeoGebra window with curve $f(x)=x^{2}$ in its graphical view and the function formula in its algebraic view. We can also see from the Figure 5 
that there is a secant line intersects the curve at point $C$ and $D$ with its slope written as " $m$ ". By using GeoGebra, we can construct point D movable along the curve of $\mathrm{f}(\mathrm{x})$ by moving point $\mathrm{B}$ along the $x$-axis. If point $\mathrm{B}$ is sliding to the left along the $x$-axis then point $\mathrm{D}$ is getting closer to point $\mathrm{C}$ along the curve, and it also applies in the opposite direction. Furthermore, as point $\mathrm{D}$ is moving along the curve then the number $m$ which represent the slope of the secant line is automatically changing.

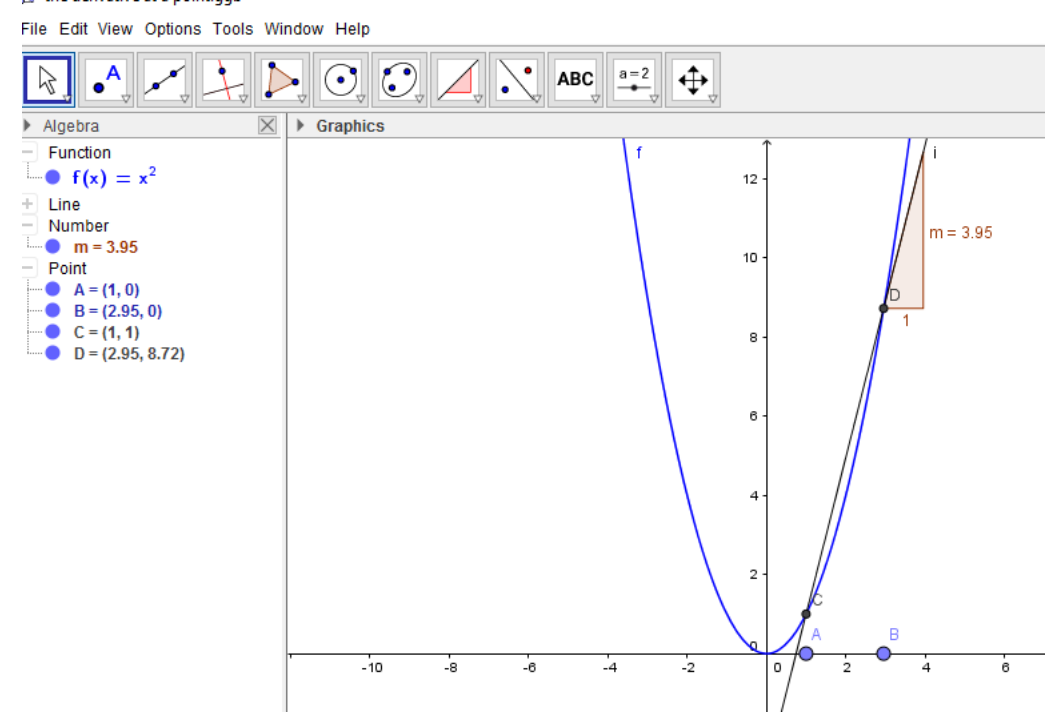

Figure 5 . Tangent line at point $(1,1)$ of the curve $f(x)$

Students already have initial knowledge about slope of a line, that is, they need at least two points on the line to be able to find the slope of the line by using formula: $m=\frac{\Delta y}{\Delta x}$. Therefore, it was assumed that they can find the slope of the secant line that pass through points $C$ and $D$ (number $m$ as the slope of the line was hiding while the teaching experiment). The following questions were expected to guide students thinking in perceiving the changing slope of the line they are what happens to the slope of the line when point D is moving closer to C?" (asked repeatedly while moving point D) and what is the slope of the line? (asked repeatedly while moving point D).

These questions will bring to the next idea of the infinitesimal distance between $\mathrm{C}$ and $\mathrm{D}$ because when point $\mathrm{D}$ is very close to point $\mathrm{C}$, students can observe in the algebra view that the coordinates of $\mathrm{C}$ and $\mathrm{D}$ differ slightly. This could be the reason why some students answered that when point $\mathrm{D}$ meets $\mathrm{C}$, then the slope of the line is zero per zero or infinite, although some of them answered zero or one as the slope of the line. However, this fact was very surprising because the students failed to relate their previous knowledge about the slope of horizontal lines which is zero and the slope of vertical lines which is infinite, and the line observed was neither horizontal nor vertical. This might happen because they depend solely on the formula $m=\frac{\Delta y}{\Delta x}$.

An anticipation was made in the hypothetical learning trajectory when students cannot perceive the infinitesimal distance between point $\mathrm{C}$ and $\mathrm{D}$. The lecturer gave a hint to students by assuming the coordinate of point $\mathrm{C}$ as $(c, f(c))$ and the coordinate of point $\mathrm{D}$ as $(c+h, f(c+h))$ where $h$ is very small. Then the discussion continued when one of the students came to the front of the classroom and wrote the expression: $m=\frac{f(c+h)-f(c)}{c+h-c}=\frac{f(c+h)-f(c)}{h}$. The lecturer gave a question: "What is happening to $m$ 
when $h$ is approaching zero?". The students answered that the secant line was transforming into a tangent line of the curve at point C. So, the question was repeated: "What is the slope of the line now?". Since none of the students came up with a solution, the lecturer explained that the slope can be determined by taking the limit of the expression when $h$ is approaching zero, that is, $m=\lim _{h \rightarrow 0} \frac{f(c+h)-f(c)}{h}$. Therefore, the definition of a tangent line below was introduced to students.

\section{Definition of Tangent Line}

The tangent line to the curve $y=f(x)$ ath the point $P=(c, f(c))$ is the line through $P$ with slope

$$
m_{\text {tan }}=\lim _{h \rightarrow 0} m_{\text {sec }}=\lim _{h \rightarrow 0} \frac{f(c+h)-f(c)}{h}
$$

Provided that this limit exist and is not $\infty$ or $-\infty$

\section{Tangent Line and Rate of Change}

After some discussion, the lesson continued by experiencing with GeoGebra. Students worked in pairs with a computer and solved the problems below. Problem 1 was chosen because it allows students to use two different methods for determining the slope of the tangent, first by estimation and second by the definition of tangent. The first method needs visualization of the problem while the second method does not.

The second problem was chosen because instantaneous velocity applies the same as the slope of the tangent line. To find the instantaneous velocity at time $t=3$ is the same as to find the slope of the tangent line to the curve of $s=t+t \cos ^{2} t$ at $t=3$. The function $s=t+t \cos ^{2} t$ was chosen because students might find difficulties in solving the problem by using the definition or maybe the rule of derivative. The solution of the problem relies to visualization of the problem. Thus, this problem was intended not only to show the connection between the tangent line and the rate of change by means of GeoGebra, but also to build students' flexibility in solving problems. GeoGebra is an easy use software, so students only need to input the formula of function in the input bar and then press the enter button. However, some assistances were provided in the classroom to use GeoGebra in solving problems (see Figure 6).

1. Consider $y=x^{3}-1$

a. Sketch its graph as carefully as you can.

b. Draw the tangent line at $(2,7)$.

c. Estimate the slope of this tangent line.

d. Calculate the slope of the secant line through $(2,7)$ and $\left(2,01,(2,01)^{3}-1\right)$

e. Find by the limit process the slope of the tangent line at $(2,7)$.

2. If a point moves along a line so that its distance $\mathrm{s}$ (in feet) from 0 is given by $s=t+t \cos ^{2} t$ at time $\mathrm{t}$ seconds, find its instantaneous velocity at $\mathrm{t}=3$.

Figure 6. Tangent line and rate of change problems (source: Varberg et al., 2006)

While students engaging in the problem, it was observed that students experienced difficulties by the instruction "estimate" in problem 1(c). GeoGebra 
provides a grid in the graphic view, so students can show the grid to be able to estimate the coordinate of another point on the line. Moreover, it is also possible to move the graphics view, zoom in and zoom out to see the details of the graphic in the coordinate system. This function helps students in solving Problem 2. Instead of using the grid, students move the graphic view until they can see the intersection between the curve's tangent and the axis. By choosing "intersect" menu in the toolbar, the points of intersection can be depicted in the graphics view and the coordinate of the point was displayed in the algebra view respectively. Therefore, they can find the slope of the tangent or the rate of change. Although GeoGebra provides the "slope" menu in the toolbar to show the slope of the tangent immediately, students experienced how to approach the problem visually (see Figure 7).

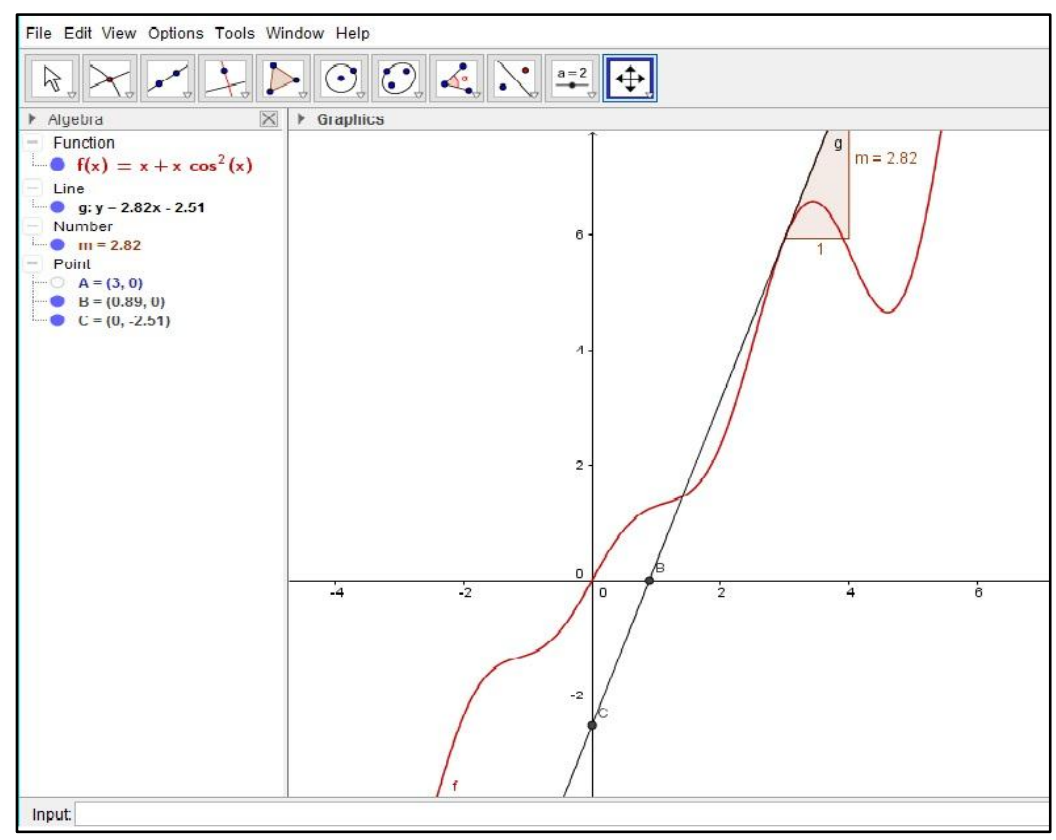

Figure 7. Tangent line at $\mathrm{x}=3$ of the curve $\mathrm{f}(\mathrm{x})=x+x \cos ^{2} x$

\section{Definition of The Derivative}

The learning goal of this lesson is that students will be able to determine the derivative of a function by using definition. Since the preceding activities built a foundation of the derivative concept, there was no crucial struggle in finding the derivative by using the definition. It was shown from the result of the midterm test where the majority of the students were able to solve the conceptual problem as shown in Figure 8.

Let $f(x)=\frac{3+x}{3-x}$.

Find $f^{\prime}(2)$ by using definition!

Figure 8. Conceptual problem

Over 44 students enrolled in the course, about $52,1 \%$ students were able to solve the problem without any mistakes, whereas $16 \%$ were failed to show the appropriate solution. However, the other $31,9 \%$ of the students were attempted to solve the problem by definition although some minor mistakes such as algebraic 
operation and arithmetical procedure occur in their solution. Therefore, we can say that the majority of the students were able to determine derivative by using definition. Figure 9 is a kind of mistakes appear in students solution, where students did not use distributive property in the expression " $3-(x+h)$ ".

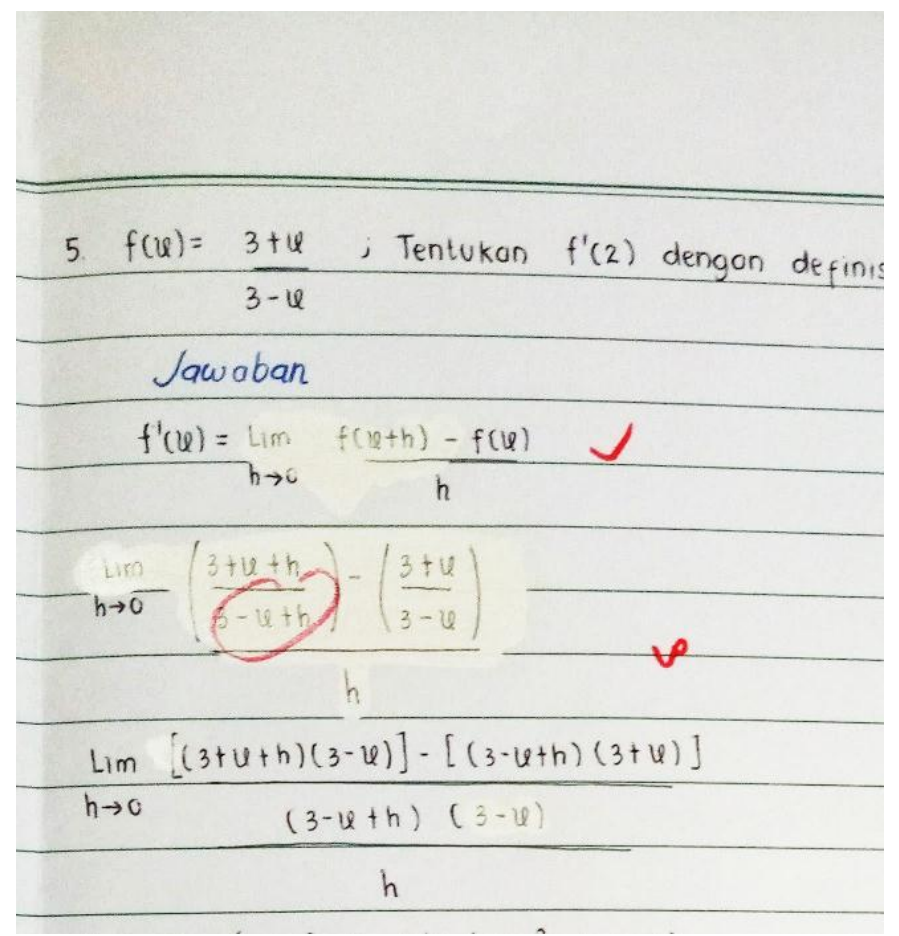

Figure 9. An example of students' mistake in dealing with definition of derivative

These findings suggest us that the dynamic feature of GeoGebra plays a significant role in the development of students' conception of the derivative. By observing how the secant line is approaching the tangent line, students experienced the limit process visually. This intuitive understanding built a foundation for the definition of the derivative. Students can explain by using the definition of derivative how the derivative function $f^{\prime}(x)=n x^{n-1}$ is derived from the function $f(x)=x^{n}$, where $n$ is a positive integer. This fact was in contrast with their previous knowledge about derivative.

\section{Constructing the Graph of the Derivative}

According to Zimmerman (1991), one of the objectives in calculus is to understand differentiation graphically. This lesson was intended to build the connection between the graph of a function and the graph of its first derivative. Therefore, students were expected to be able to sketch the graph of the first derivative function based on the graph of the function.

To demonstrate how GeoGebra can be used to see the relationship between the graph of a function and the graph of its first derivative, the graph of $f(x)$ and a tangent line at any point were drawn. Since the slope of the tangent line is equal to the $y$ coordinate of the first derivative function, then plotting the point $\left(c, f^{\prime}(c)\right)$ along the domain of the function will create the graph of the first derivative. This can be shown dynamically by using GeoGebra when every point $\left(c, f^{\prime}(c)\right)$ in the domain is tracing by sliding the slider that represent the slope of the curve's tangent. (see Figure 10). The 
curve's tangent is sliding along the curve when the slider is moving, while at the same time the point $\left(c, f^{\prime}(c)\right)$ is plotted

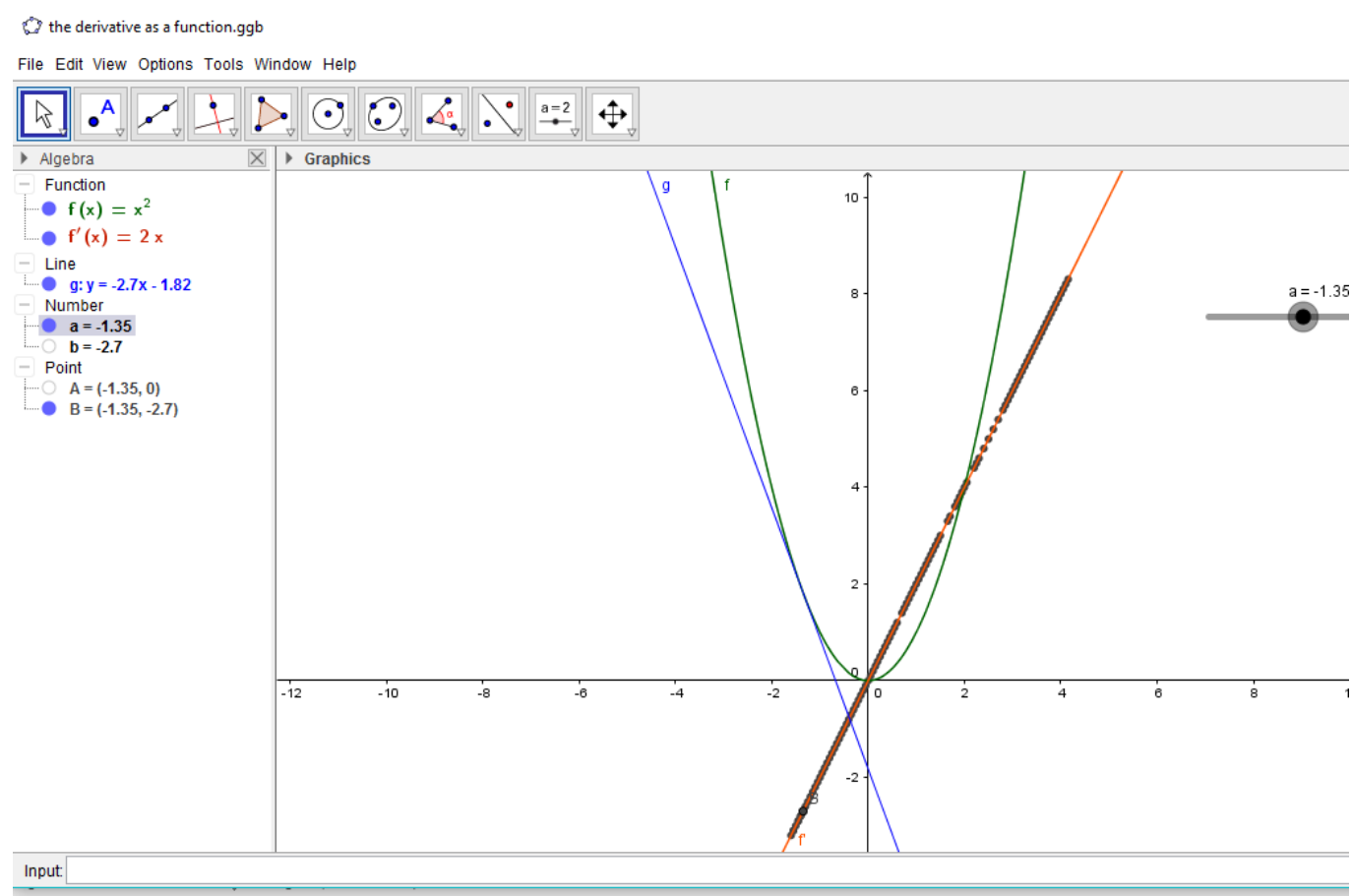

Figure 10. GeoGebra's interface for visualizing the graph of derivative

At this point, by observing how GeoGebra represents the changing of slope dynamically, students were expected to be able to perceive 1) The value of the slope of a curve's tangent at $x=c$ equals $f^{\prime}(c)$. 2) The graph of the first derivative function can be constructed by plotting points $\left(c, f^{\prime}(c)\right)$ along the domain of the function. 3 ) As the tangent line moving along the curve, the slope value is changing. In the interval when the tangent line is sloping upwards it gives positive slope, that is the point $\left(c, f^{\prime}(c)\right)$ will always be above the $x$-axis. In the interval when the tangent line is sloping downwards it gives negative slope, that is the point $\left(c, f^{\prime}(c)\right)$ will always be under the $x$-axis, and the horizontal tangent gives the zero slope. 4) Consequently, students will be able to see the connection between this representation and the extreme value of a function, that is the function will reach its extreme value when the first derivative of the function equals zero.

1. Estimate $g^{\prime}(-1), g^{\prime}(1), g^{\prime}(4)$, and $g^{\prime}(6)$ from the graph below

2. Sketch the graph of $y=g^{\prime}(x)$

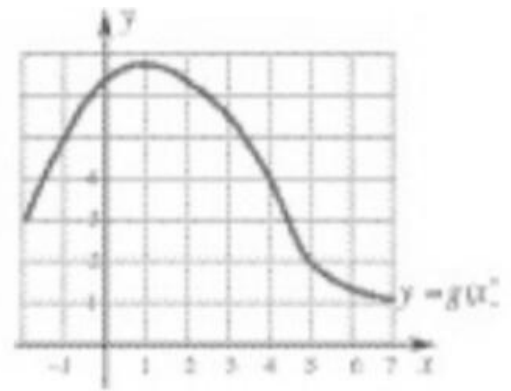

Figure 11. Constructing the graph of the first derivative 
During the lesson, students had difficulties in translating the slope of a tangent into the graph of the derivative. Once again, they were confronted with the word "estimate" in the above problem (see Figure 11). The problem depends solely on visual thinking where students have to estimate the value of $g^{\prime}(-1), g^{\prime}(1), g^{\prime}(4)$, and $g^{\prime}(6)$. In other words, students have to find the slope of tangent to the curve at $x=-1, x=1, x$ $=4$, and $x=6$. It took quite much time in dealing with this problem until they finally can feel the sense of estimating.

Therefore, the results show that the first activity "approaching tangent line from secant line " in the hypothetical learning trajectory built the foundation of students' conceptual understanding of the derivative definition. The result is in line with Tall (2009) that tracing the changing slope of a curve's tangent gives a physical embodiment of a curve's tangent that can be estimated numerically or investigated symbolically to give a precise description. Moreover, by providing the dynamic-visual representation of the tangent line from a secant line, the students could observe the infinitely small distance $(d s)$ as explained by Leibniz in the Leibniz triangle. Thus, the term $h \rightarrow 0$ in the limit process of $m=\lim _{h \rightarrow 0} \frac{f(c+h)-f(c)}{h}$ become make sense for the students.

Hohenwarter (2008) explained that by using GeoGebra, students are able to construct, manipulate, and give arguments about mathematical objects. In the next activity, the students were provoked by a problem that can not be solved easily by the rule of derivative (Figure 6, no.2). It was shown in the result that some students found difficulties in finding the derivative of function $s=t+t \cos ^{2} t$ by applying the rule of derivative. By providing such type of function, students were forced to see that by visualizing the function using GeoGebra, they can easily construct the graph of the function, the tangent line at $x=3$, and then find another point on the tangent line to compute the slope of the tangent. This activity was expected to build students' sense of estimating when they were dealing with the next activity in the learning trajectory.

According to Zimmerman (1991), students should be able to sketch the graph of the derivative, given a graph of a function. This ability connects many ideas related to the derivative, such as critical points, inflection points and other characteristics of curves. Thus, the last activity "constructing the graph of derivative" was designed. However, the results show that the connection between the ideas of the derivative was not obvious for the students. This fact suggests us to give more experience to students in working with GeoGebra more often and to observe how the graph of the derivative is constructed dynamically. Although the dynamic characteristics of GeoGebra have the potentials to enhance students thinking for exploring the concept of derivative, the students should have more experienced and get involved in working with GeoGebra.

\section{CONCLUSION}

This study explores how GeoGebra is used to present a dynamic approach in introducing derivative. First, GeoGebra is used to visualize dynamically the infinitesimal element in the concept of derivative, that is by designing the first activity - approaching the tangent line to a curve from a secant line. By doing so, the limit process when the secant line approaches the tangent line becomes to make sense. Hence, students show their understanding of the derivative definition. This activity builds a strong foundation so that the students can determine the derivative of a function algebraically by using the definition. Moreover, GeoGebra not only gives the geometric representations of a situation but also provides possibilities of approaching problems from different perspectives. By providing the means GeoGebra and the 
chosen problems, students gradually shift their algebraic thinking and start thinking geometrically in solving the problem.

The last activity, that is constructing derivative graph have potentials to enhance students understanding for further studies of calculus. However, the data suggest that students still have difficulties in connecting multiple representations of a concept at the same time, that is the derivative of a function at a point, the slope of the tangent at the point, and the value of the function for the derivative function. Therefore, it is suggested that by providing students with dynamic representations of derivative using GeoGebra, they will be able to see mathematical objects from different perspectives and build the connection among the multiple representations.

\section{REFERENCES}

Ahuja, O.P., Lim-Teo, Suat-Khoh and Lee, Peng Yee. (1998). Mathematics Teachers' Perspective of Their Students' Learning in Traditional Calculus and Its Teaching Strategies. Journal of the Korea Society of Mathematical Education Series D: Research in Mathematical Education, 2(2), 89-108.

Amiel, T., Reeves, T. C. (2008). Design-Based Research and Educational Technology: Rethinking Technology and the Research Agenda. Educational Technology and Society, 11(4), 29-40.

Cobb, P., Stephan, M., McClain, K., and Gravemeijer, K. (2001). Participating in Classroom Mathematical Practice. The Journal of the Learning Science, $10(1 \& 2)$, 113-163.

Cobb, P., Confrey, J., diSessa, A., and Lehrer, R. (2003). Design Experiments in Educational Research. Educational Researcher, 32(1), 9-13.

Diković, L. (2009). Applications GeoGebra into Teaching Some Topics of Mathematics at the College Level. ComSIS, 6(2), 191-203.

Edelson. D. C. (2002). Design Research: What We Learn When We Engage in Design. The Journal of The Learning Sciences, 11(1), 105-121.

Gravemeijer, K., and Cobb, P. (2006). Design Research from a Learning Design Perspective, Educational Design Research. London and New York: Routledge,

Gravemeijer, K., and Doorman, M. (1999). Context Problems in Realistic Mathematics Education: a Calculus Course as an Example. Educational Studies in Mathematics, 39(1-3), 111-129.

Haciomeroglu, E. S., and Andreasen, J.B. (2013). Exploring Calculus with Dynamic Mathematics Software. Mathematics and Computer Education, 47(1), 6-18.

Haciomeroglu, E. S., Aspinwall, L., Presmeg, N.C. and Knott, L. (2009). Visual and Analytic Thinking in Calculus. The Mathematics Teacher, 103(2), 140-145.

Haciomeroglu, E. S., Aspinwall, L. and Presmeg, N. (2010). Contrasting Cases of Calculus Students' Understanding of Derivative Graphs. Mathematical Thinking and Learning, 12(2), 152-176.

Hohenwarter, M., Hohenwarter, J., Kreis, Y., and Lavicza, Z. (2008). Teaching and Learning Calculus with Free Dynamic Mathematics Software GeoGebra, TSG 16: Research and development in the teaching and learning of calculus, ICME 11, Monterrey, Mexico. 
Kleiner, I. (2001). History of the infinitely small and the infinitely large in calculus. Educational Studies in Mathematics, 48(2-3), 137-174.

Lee, P. Y. (2006). Teaching Secondary School Mathematics. Singapore: Mc Graw Hill.

Özmantar, M. F., Akkoc, H., Bingolbali, E., Demir, S., and Ergene, B. (2010). Pre-Service Mathematics Teachers' Use of Multiple Representations in Technology-Rich Environments. Eurasia Journal of Mathematics, Science \& Technology Education, 6(1), 19-36.

Rasmussen, C., Marrongelle, K., and Borba, M.C. (2014). Research on calculus: what do we know and where do we need to go. ZDM, 46(4), 507-515.

Simon, M. A. (1995). Reconstructing Mathematics Pedagogy from a Constructivist Perspective. Journal for Research in Mathematics Education, 26(2), 114-145.

Struik, D. J. (Ed.). (1969). A source book in mathematics, 1200-1800. Cambridge: Harvard University Press.

Tall, D.O. (2009). Dynamic mathematics and the blending of knowledge structures in calculus. ZDM, 41(4), 481-492.

Varberg, D., Purcell, E., and Rigdon, S. (2006). Calculus $9^{\text {th }}$ Edition. New York: Pearson.

Weigand, G. H. (2014). A Discrete Approach to the Concept of Derivative. ZDM, 46(4), 603-619.

Zimmerman, W. (1991). Visual Thinking in Calculus. In W. Zimmermann and S. Cunningham (Editors), Visualization in Teaching and Learning Mathematics (pp. 127-138). Washington, DC: Mathematical Association of America. 
